i javnog života muslimana ni na nivou osobnog religijskog života pojedinaca niti su im iste manifestacije « (str. 172), odnosno sekularizacijski su procesi manje izraženi u prostoru javnoga (što ne usporava procese diferencijacije društvene strukture), a potaknuti su događanjima vezanima uz raspad socijalizma i stvaranje novih nacionalnih država, koje svoju legitimaci- ju traže u polju religijskoga. Isto tako, na području osobnoga religijskog života postoji preklapanje konfesionalnosti i religioznosti, izraženija konfesionalna pripadnost pretpostavlja jače očitovanje religije, ali ne i dosljednost vjerničkog života.

Nikolina Hazdovac Bajić

Institut društvenih znanosti »Ivo Pilar«, Dubrovnik
Anđelko Milardović

\section{Stranac i društvo: fenomenologija stranca i ksenofobija}

Zagreb: Pan Liber, 2013, 248 str.

DOI: $10.11567 /$ met.29.3.7

U izdanju Pan Libera 2013. godine objavljena je knjiga politologa Anđelka Milardovića Stranac i društvo: fenomenologija stranca $i$ ksenofobije. Najnovija Milardovićeva knjiga nastala je kao dio znanstvenoga projekta »Interkulturni pristup etničkoj različitosti i identitet: Hrvatska - Europa « koji se provodio $u$ Institutu za migracije i narodnosti od 2008. do 2013. Prema autorovim riječima, knjiga je duboko motivirana osobnim i širim obiteljskim iskustvom života izvan domovine, životom »iskorijenjenog čovjeka« - stranca te željom da se tom iskustvu dade znanstveni okvir.

Knjiga Stranac i društvo pisana je multidisciplinarno, kombinirajući znanstvene spoznaje sociologije, etike, filozofije, povijesti, prava, antropologije, psihologije, lingvistike i politologije s posebnim fokusom na fenomenologiji stranaca pod utjecajem Alfreda Schütza, Georga Simme- la i čikaške sociološke škole. Fenomen stranca star je koliko i čovjek, odnosno kao društvo, kultura i civilizacija. Kao društveno biće između dviju kultura, stranac ima svoju »sudbinu « od početaka kultura i civilizacija pa sve do postmodernoga globaliziranoga društva.

Autorova je polazišna teza da se $» u$ svim društvima tijekom povijesti civilizacija, uključujući i današnje suvremene civilizacije i društva, odnos prema strancu temeljio na minimalnoj integraciji, isključivanju i neprijateljstvu te racionalnom i iracionalnom strahu« (str. 213). Odnos prema strancu zapravo je odnos prema Drugome, a markeri koji razlikuju Prooga i Drugoga jesu jezik i kultura, što ne znači da stranci ne postoje i unutar istog jezika i iste kulture. Odnos prema Proome temelji se na identitetu, odnosno istovjetnosti, a odnos prema Drugome na razlici, odnosno drugosti.

Knjiga je podijeljena na dva velika poglavlja: »Teorijsko-metodološka pitanja «, koje se sastoji od četiriju analitika: Temeljni pojmovi i teorija, Stranci u povijesti kultura i civilizacija, Slike stranca kao mogućeg Drugog i Slike straha, te »K sociologiji stranca i ksenofobije«, koje obuhvaća pet analiti- 
ka: Stranac kao društveni tip, Stranac na rubu društva, Stranac kao mogući Drugi, Slika stranca u modernim i političkim ideologijama te Stranac, društvo i kultura u doba globalizacije.

Nakon opširne analize temeljnih pojmova i teorija o strancu u pojedinim društveno-humanističkim znanostima te njegove povijesti osobito je zanimljiv dio knjige o slici stranca kao Drugoga. Stranac se doživljava i doživljavao se kroz povijest kao: barbarin, tuđin, neprijatelj, socijalni tip, migrant, čovjek koji je došao da ostane, lutalica, most, biće između, neukorijenjen, povratnik, prijatelj, kozmopolit i dr. Posebice je interesantna slika stranca posredovana stereotipima i predrasudama koji egzistiraju u svim društvima i kulturama. I jedni i drugi zamišljene su slike koje imamo o strancima, odnosno Drugima. Stereotipi su, tvrdi autor, preuzimajući Allportovo stajalište, generalizacije, odnosno racionalne i pojednostavljene kategorizacija na temelju zajedničkih obilježja skupine (prema Dubravki Oraić Tolić, dijele sa na autostereotipe i heterostereotipe), a na njihovo širenje uvelike utječu mediji. Koristeći se Allportovim spoznajama o predrasudama, Milardović definira predrasude kao »socijalno-psihološku slika stranca kao radikalnog i ekskluzivnog neprijateljskog odnosa prema strancima kao pripadnicima vanjske grupe« (str. 82).

U prvom se poglavlju posebno problematizira osjećaj straha, koji je javlja u rasponu od egzistencijalnoga preko iracionalnoga pa sve do psihopatološkoga. Strah vodi ksenofobiji popraćenoj mržnjom i agresijom, što može dovesti do konflikata među društvenim skupinama. Ksenofobija se, ističe autor, može tumačiti u različitim kate- gorijama kao što su: iracionalni strah, mržnja, predrasude, diskriminacija, etnocentrizam, neprijateljstvo, netolerancija, šovinizam, nacionalizam, isključivanje stranaca iz multikulturnih društava, a često se javlja u doba krize, pa može poprimiti i obilježja socijalne panike. Milardovićev zaključuje prvo poglavlje stavom da ksenofobija i islamofobija na Zapadu nastaju zapravo kao populistički odgovor na globalizaciju.

U drugom poglavlju autor promatra stranca kao konkretnu osobu, individuu u društvu. Živeći u društvu, čovjek dolazi u različite međugrupne interakcije, od kojih je jedna i odnos prema strancu. Tako danas postoji cijela grana sociologije koja se bavi fenomenologijom stranaca, čiji su glavni predstavnici Georg Simmel, Robert Michels, Robert E. Park, Alfred Schütz, Paul C. P. Siu, Ulf Hannerz, Rudolf Stichweh i Zygmunt Bauman. U ovom se poglavlju prikazuje i slika stranca u modernim i političkim ideologijama. Tako primjerice liberalizam i neoliberalizam imaju prema strancu odnos tolerancije na distancu, socijaldemokracija i komunizam odnos između tolerancije i isključivanja, konzervativizam skepticizam, nacionalizam izolaciju i isključivanje, fašizam i nacionalsocijalizam odnos radikalne izolacije i ekstremnog isključivanja popraćenog fizičkim uništenjem, nova desnica ima odnos sofisticiranoga (metapolitičkog) isključivanja, a populistička radikalna desnica odnos tvrdoga, populističkog isključivanja.

Autor zaključuje da u današnjem svijetu supostoje dva procesa: globalizacija i antiglobalizacija. Globalizaciju obilježavaju multikulturalizam i tolerancija, odnosno uključivanje, a an- 
tiglobalizaciju etnocentrizam i ksenofobija, odnosno isključivanje. Globalizacija, kao izraz modernizacije i kao integracija svijeta, na razini lokalnih društava i nacionalnih država generira antiglobalizacijska djelovanja u obliku desnih radikalnih stranaka i pokreta s markerima kao što su antiimigracija, suprotstavljanje multikulturalizmu, ksenofobija i islamofobija. Svjedoci smo da se danas pojavljuju nove desnice $\mathrm{u} t \mathrm{zv}$. visokorazvijenim zemljama: Njemačkoj, Francuskoj, Nizozemskoj, Austriji, Danskoj, Velikoj Britaniji, Svedskoj i Italiji.
$\mathrm{Na}$ eventualno pitanje čitatelja kako u današnje doba ublažiti pojavu neprijateljstva prema strancima uzrokovanu etnocentrizmom autor daje jedan od mogućih odgovora: kontaktima unutarnjih i vanjskih skupina te integracijom i akulturacijom - naravno, sve to pod pretpostavkom tolerancije.

Dinka Pasini

Filozofski fakultet Sveučilišta u Zagrebu, Zagreb
Edvin Pezo

\section{Zwangsmigration in Friedenszeiten? Jugoslawische Migrationspolitik und die Auswanderung von Muslimen in die Türkei (1918 bis 1966)}

München: Oldenbourg Verlag, 2013, 374 str. (Südosteuropäische Arbeiten, 146)

DOI: 10.11567/met.29.3.8

U odgovoru na još uvijek polemičko pitanje pripada li islam povijesnom naslijeđu Europe njemački povjesničar Edvin Pezo u uvodu svoje iznimne studije Zwangsmigration in Friedenszeiten? Jugoslawische Migrationspolitik und die Auswanderung von Muslimen in die Türkei (1918 bis 1966) podsjeća na činjenicu da je jugoistok europskog kontinenta od 14. stoljeća bio dio Osmanlijskoga Carstva te je time islam zauvijek ostavio traga u Europi i udomio značajnu muslimansku populaciju. I dok je, s jedne strane, osmanlijsko povlačenje s jugoistoka Europe bilo u pravilu popraćeno značajnim iseljavanjem Turaka i drugih muslimana, s druge strane, unatoč stalnim ili povremenim emigracijskim valovima, muslimanske su zajednice ostale do danas integralni dio regije. Tako znatan broj Turaka živi u južnim i sjeveroistočnim dijelovima Bugarske te $\mathrm{u}$ krajevima koji su činili bivšu Jugoslaviju, najviše u Makedoniji. Osim Turaka i Albanci tvore značajnu skupinu muslimana kao i regionalne koncentracije slavenskog stanovništva koje se islamiziralo, najbrojniji su u Bosni i Hercegovini i u Sandžaku, a brojni su i u Bugarskoj i Grčkoj. I, konačno, značajni postotak Roma, raširen po svim zemljama jugoistočne Europe, čine također muslimani. Činjenica da su spomenute države, s izuzetkom Albanije, u osnovi kršćanske činilo je (čini) položaj muslimanskih zajednica unutar njih posebno problematičnim. Ideologija koja tumači da je država prirodni teritorij jedne dominantne etničke/ nacionalne skupine znači u praksi da politička i ekonomska moć pripada samo većinskom narodu, s minimal- 